\title{
EKSEKUSI SEPIHAK OLEH PERUSAHAAN LEASING MENGGUNAKAN DEBT COLLECTOR TERHADAP OBYEK JAMINAN FIDUSIA
}

\author{
Kelik Endro Suryono, Guruh Riona Putra \\ Fakultas Hukum Universitas Widya Mataram \\ nDalem Mangkubumen KT III/ 237, Yogyakarta \\ keliksuryono63@gmail.com
}

\begin{abstract}
Abstrak
Manusia dalam memenubi kebutuban secara alamiah akan selalu mencari peluabg/celah, dalab suatu hal untuk. memenubi kebutuhannya, kebutuban atau keinginan tersebut untuk memiliki sesuatu untuk yang bersifat konsumtif ataupun sebagai saranal modal usaba, maka kemudian kebutuban dan/ peluang bisnis di bidang leasing. Perusahaan pembiayaan ini menghadapi dilemma ketika konsumen/nasabah nya wanprestasi atau telat atau gagal bayar (bad debt). Perusabaan leasing akan berupaya mengembalikan hak nya yaitu baran yang telah menjadi jaminan fidusia, sepintas Nampak bubungan keperdataan, tapi kita ketabui bersama seringkali upaya untuk mengembalikan bak perusahaan leasing ini kesulitan, akbirnya beberapa dari perusabaan ini menggunakan jasa debt collector eksternal, atau karyawan perusahaan yang bertugas menjadi debt collector, disini akan menimpulkan implikasi bukum yang kompleks yaitu perdata dan kemungkinan pidana terkait upayal tindaka dari debt collector, terbap eksekusi jaminan fidusia secara sepibak. Maka pemerintah menerbitkan berbagai regulasi untuk melindungi para pihak, yaitu konsumen/nasabah yang acapkali menjadi pihak yang dirugikan/ subordinat, disisi lain keberlangsungan perushaan leasing (atau perusahaan apapun) adalah unsur penggerak perekonomian nasional. Maka penulis melakukan penelitian normative yang komprehensif dari sudut pandang perdata maupun pidana.
\end{abstract}

Kata Kunci: perusahaan leasing, wanprestasi, debt collector, eksekusi, jaminan fidusia

\section{A. Pendahuluan}

Pelaku ekonomi lokal (bisnis) muncul sebagai pendorong pembangunan berkelanjutan di sebuah Negara, salah satu faktor yang menyumbang pertumbuhan ekonomi adalah perusahaan leasing, sebagai lembaga yang membantu menjembatani kebutuhan masyarakat untuk membeli benda bergerak (kendaraan/ sepeda motor), yang 
masih terjadi di negara-negara berkembang seperti halnya Indonesia atau di sebagian besar wilayah asia tenggara.

Perkembangan perusahaan leasing cukup pesat di indonesia, jenis - jenis barang yang dibiayaipun semakin bervariasi tidak sebatas di bidang sarana transportasi tetapi juga berkembang ke sektor industri, telekomunikasi, pertanian dan lain sebagainya. Pembiayaan yang dilakukan oleh pihak leasing dituangkan dalam perjanjian kredit antara pihak leasing dengan debitor.

Kebutuhan masyarakat terhadap pendanaan yang merupakan kebutuhan dan perkembangan ekonomi masyarakat di satu sisi, dan keterbatasan penyaluran kredit perbankan pada sisi lain, telah menjadi salah satu sebab maraknya tumbuh lembaga keuangan non bank, yang secara umum disebut dengan "leasing", dalam operasionalnya menyelenggarakan sebagian layanan layaknya lembaga perbankan, yaitu menyelenggarakan atau menyalurkan kredit pada masyarakat. adanya berbagai ragam perusahaan lembaga pembiayaan ini, memang merupakan kebutuhan penggerak ekonomi, baik yang diselenggarakan oleh pemerintah maupun swasta. ${ }^{1}$

Di dalam perjanjian pembiayaan tersebut biasanya pihak leasing mencantumkan kata-kata dijaminkan secara fidusia, yang artinya bahwa didalam perjanjian kredit (sebagai perjanjian pokok) menimbulkan adanya perjanjian jaminan fidusia (sebagai perjanjian assesoir) yang membebani benda yang dibiayai dijadikan sebagai jaminan pelunasan atas hutang apabila suatu saat nanti terjadi kredit macet atau wanprestasi.

Selain itu Pembebanan benda yang dijadikan sebagai jaminan fidusia haruslah di daftarkan pada kantor pendaftara fidusia hal ini sebagaimana diatur dalam Pasal 11 ayat (1) UUJF Pendaftaran jaminan fidusia dilakukan paling lambat 1 (satu) bulan setelah dilakukannya perjanjian kredit atau pembiayaan. Sertifikat jaminan fidusia haruslah dibuat di kantor notaris sebagaimana diatur dalam Pasal 5 ayat (1) UUJF.

Dengan didaftarkannya jaminan fidusia akan memudahkan pihak leasing untuk melakukan eksekusi jaminan fidusia apabila suatu saat nanti terjadi kredit macet atau cidera janji. Akan tetapi fakta yang ditemukan dilapangan, banyak ditemukan perusahaan leasing yang tidak mendaftarkan jaminan fidusia, dan dalam prakteknya penyitaan jaminan oleh pihak leasing dilakukan secara paksa tanpa adanya pemberitahuan kepada

${ }^{1}$ Made Warka, Sudarti, 2014, “Pengambilan Paksa Kendaraan Bermotor Dan Upaya Hukum Konsumen”, Jurnal Ilmu Hukum Mimbar Keadilan, Mei - Nopember, h. 94 
Kelik Endro Suryono, Gurub Riona Putra: Eksekusi Sepibak Oleh Perusabaan Leasing...

debitor terlebih dahulu. Walaupun pendaftaran jaminan fidusia sangat penting untuk dilakukan, tetapi dalam praktiknya ada saja kreditor yang tidak mendaftarkannya, maka akibatnya adalah tidak memiliki sifat droit de suite. ${ }^{2}$ Adapula yang menyiasati pendaftaran jaminan fidusia dengan jalan tengah/ celah hukum dengan mengutip pendapat Peter Giovanni, bahwa sikap bank menunjukkan kurangnya profesionalitas dalam proses melaksanakan kegiatan usahanya karena dengan adanya perjanjian fidusia dibawah tangan yang dibuat bank tidak sesuai dengan Undang-Undang Jaminan Fidusia sehingga tanggung jawab bank dan kinerja bank dengan prinsip kehati-hatian perlu dipertanyakan. ${ }^{3}$ Disini posisi bank adalah sama dengan posisi/peran perusahaan leasing, yaitu sebagai kreditor.

Hal ini menimbulkan problem terhadap perlindungan hukum, Satjipto $\mathrm{R}$, berpendapat bahwa perlindungan hukum adalah upaya memberikan pengayoman terhadap hak asasi seseorang yang dirugikan pihak lain dan agar masyarakat untuk dapat menikmati semua hak-hak yang diberikan oleh hukum ${ }^{4}$

yang dimana penyitaan jaminan secara sepihak dengan paksaan tanpa adanya akta jaminan fidusia tersebut bertentangan dengan ketentuan yang berlaku dalam UUJF dan Peraturan Kapolri No. 8 Tahun 2011. Selain itu yang menjadi permasalahan yang ada yaitu mengenai siapa yang berhak atas jaminan fidusia tersebut apabila debitor tidak mampu membayar angsuran kredit. Terkait hak eksekusi atas benda yang dibeli secara angsuran terdapat perbedaan regulasi antara UU Perlindungan konsumen (UUPK) dengan UU jaminan fidusia (UUJF).

Dalam ketentuan Ps. 18 ayat (1) huruf d dan f UUPK melarang pelaku usaha untuk mencantumkan klausa baku dalam perjanjian pembiayaan mengenai pemberian kuasa atas benda tersebut kepada pihak pelaku usaha untuk mengurangi manfaat jasa ataupun harta kekayaan konsumen yang menjadi obyek jual beli jasa apabila terjadi kredit macet atau cidera janji. Sedangakn dalam Ps. 15 ayat (3) UUJF mengatur bahwa penerima

\footnotetext{
${ }^{2}$ Kadek Cinthya Dwi Lestari*, I Nyoman Putu Budiartha dan Ni Made Puspasutari Ujianti, 2020, “Hilangnya Objek Jaminan Fidusia yang Tidak Didaftarkan”, Jurnal Analogi Hukum, 2 (3), h. 385

3 Peter Giovanni Handoko Suwigjo Putro, 2017, “Analisis Terhadap Dampak Dibuatnya Jaminan Fidusia Dengan Perjanjian Dibawah Tangan Oleh Bank Perkreditan Rakyat”, Jurnal Hukum Uajy, Agustus, h.3

${ }^{4}$ Hartanto, Cut Wilda Meutia Syafiina, 2021 "Efektivitas Perlindungan Konsumen Terhadap Produk Kosmetik Yang Tidak Memiliki Izin Edar Balai Besar Pengawas Obat Dan Makanan Diy (Dalam Perspektif Hukum Pidana)", Jurnal Meta-Yuridis Vol 4, No 1, h.62
} 
fidusia memiliki hak untuk menjual benda yang dijadikan objek jaminan fidusia atas kehendaknya sendiri.

Salah satu hal yang bisa mendukung kecepatan mobilitas masyarakat adalah kendaraan bermotor. Kendaraan bermotor dapat membawa manusia ataupun barang dari satu tempat ke tempat lain dengan cepat dan dalam jumlah yang banyak. Secara umum jenis kendaraan bermotor yang digunakan ada dua jenis, yaitu sepeda motor dan mobil. Sepeda motor mempunyai harga yang lebih murah daripada mobil, akan tetapi mempunyai muatan yang lebih sedikit. Di lain pihak, mobil mempunyai muatan yang lebih banyak, namun harganya lebih mahal.

Dalam praktek pelaksanaan pembiayaan leasing ini, walaupun secara aktual pembeli telah sangat terbantu dengan adanya perusahaan pembiayaan, namun sering kali pihak pembeli tidak menunjukkan itikad baik dengan melunasi biaya angsuran yang timbul dari pembelian sepeda motornya. Hal ini terlihat dari banyaknya bad debt yang terjadi. Adanya bad debt ini menyebabkan kerugian bagi perusahaan pembiayaan karena membuat modal tidak kembali. ${ }^{5}$

Dalam menyelesaikan masalah bad debt ini, hukum memiliki peranan yang sangat penting. Untuk itu sangat penting diketahui hubungan hukum antara pihak pembeli dan perusahaan pembiayaan. Setelah diketahui bagaimana hubungan hukum antara kedua pihak tersebut, maka dapat ditentukan penyelesaian hukum yang tepat untuk menyelesaikan masalah tersebut.

\section{B. Telaah Konsep}

Penelitian terkait wanpretasi dalam binis keuangan perusahaan leasing telah banyak diteliti, namun disini penulis mencoba menyajikan perihal yang lebih spesifik terkait peranan debt collector yang dapat dikaji dari sudut pidana dan juga asumsi umum bahwa pihak kreditor dianggap tetap memiliki hak atas benda bergerak (kendaraan) sepanjang belum lunas. Nampaknya disini perlinudngan hukum konsumen akan upaya debt collector yang melakukan pekerjaannya sangat rentan bersinggungan dengan hukum pidana, dan pada pembatalan sebuah perjanjian kredit karena wanpretasi tidak otomatis memberikan hak seluas-luasnya kepada kreditor untuk melakukan eksekusi sepihak. Dalam hal ini peneliti mencoba menyajikan dengan lebih dalam. Penulis memberikan pendapat dalam

\footnotetext{
${ }^{5}$ Irsan, Koesparmono. 2010, Kasus-Kasus Debt Collector di Indonesia, Sinar Grafika, Semarang.h.76
} 
Kelik Endro Suryono, Gurub Riona Putra: Eksekusi Sepibak Oleh Perusabaan Leasing...

hal penggunaan istilah kreditur dan debitur, dan kreditor dan debitor, bahwa lebih banyak peraturan perundang-undangan yang menggunakan istilah kreditor dan debitor, meski lebih tepat penggunaanya berdasar Undang-undang apa yang dirujuk.

\section{Metode Penelitian}

Sifat dan jenis penelitian ini adalah deskriptif normatif. Deskriptif adalah mengambarkan secara jelas dan konkrit terhadap objek permasalah tentang wanprestasi terhadap debitor yang dieksekusi secara sepihak oleh debt collector dalam perajanjian leasing dengan jaminan fidusia, sedanbgkan sebagai pendukung adalah adanya pembatasan obyek dan/ narasumber di perusahaan FIF, hal ini berdasarkan fakta yang terjadi di lapangan. Sedangkan maksud normatif adalah pengkajian obyek permasalahan yang didasarkan atas ketentuan-ketentuan hukum (hukum positif) yang berlaku. Berdasarkan hal tersebut di atas maka penelitian merumuskan judul: Eksekusi Sepihak Oleh Perusahaan Leasing Menggunakan Debt Collector Terhadap Obyek Jaminan Fidusia.

\section{Pembahasan}

\section{Eksekusi Secara Sepihak Oleh Debt Colector Dalam Perjanjian Leasing}

\section{Dengan Jaminan Fidusia}

Akibat hukum debitor wanprestasi pada perusahaan lembaga pembiayaan konsumen adalah, kreditor tidak mendapatkan pemenuhan hak-haknya yang semestinya didapatkan dengan adanya perjanjian tersebut. Hal ini terjadi karena hubungan hukum yang terjadi antara debitor dengan perusahaan leasing didasarkan pada adanya sebuah perjanjian yakni perjanjian pembiayaan konsumen. Secara yuridis, akibat hukum dari wanprestasi dalam suatu perjanjian tidaklah sesederhana itu. Sebab perjanjian sebagai ikatan dalam bidang hukum perdata antara dua subjek hukum atau lebih, dimana satu pihak berhak atas sesuatu dan pihak yang lainnya berkewajiban untuk melakukannya.

Berdasarkan hasil wawancara dengan CMO (Credit Marketing Officer) PT FIF Federal International Finance Yogyakarta dapat diketahui bahwa terdapat beberapa 
permasalahan yang timbul dalam pelaksanaan perjanjian pembiayaan konsumen pada kantor Yoigyakarta, yaitu sebagai berikut : ${ }^{6}$

1. Debitor tidak memenuhi salah satu kewajibannya yang ditentukan dalam perjanjian, yakni tidak membayar angsuran dengan lewatnya waktu 30 (tiga puluh) hari sejak tanggal jatuh temponya angsuran.

2. Debitor tidak menjaga dan merawat barang jaminan yakni sepeda motor dari kemungkinan rusak atau hilang.

3.Debitor menjual, meminjamkan, atau melakukan hal-hal lain yang menyebabkan beralihnya sepeda motor kepada pihak ketiga dengan bentuk dan cara apapun tanpa sepengetahuan pihak kreditor, seperti misalnya sepeda motor biasanya diperuntukkan untuk orang lain dimana jika suatu saat orang yang menggunakan sepeda motor tersebut hilang bersama dengan sepeda motornya maka atas nama kredit biasanya menghindar/ keberatan dari tanggung jawab terhadap pembayaran angsuran.

Adapun ukuran yang dipakai untuk menentukan debitor telah melakukan wanprestasi pada PT FIF Federal International Finance Yogyakarta, antara lain :

1.Tidak dibayarnya angsuran hutang pembiayaan dengan lewatnya waktu 30 (tiga puluh) hari sejak tanggal jatuh temponya angsuran.

2.Sepeda motor/ mobil digadaikan

3.Sepeda motor dibawa keluar daerah

4.Dilakukan over kredit tanpa sepengetahuan pihak PT FIF Federal International Finance Yogyakarta

Untuk penyelesaian wanprestasi pada PT FIF Federal International Finance Yogyakarta, debitor pertama-tama akan disomasi atau diberikan SP (Surat Peringatan) oleh collector, dimana masing- masing sebagai berikut:

1.Surat Peringatan 1 diberikan kepada debitor yang terlambat melakukan pembayaran selama 1 bulan atau 30 hari.

2.Surat Peringatan 2 diberikan kepada debitor yang terlambat melakukan pembayaran selama 2 bulan atau 60 hari.

${ }^{6}$ Wawancari CMP PT. FIF Agustus 2020 
Kelik Endro Suryono, Guruh Riona Putra: Eksekusi Sepibak Oleh Perusahaan Leasing...

3.Surat Peringatan 3 diberikan kepada debitor yang terlambat melakukan pembayaran selama 3 bulan atau 90 hari.

Jika dalam tenggang waktu 3 bulan atau 90 hari debitor tetap tidak bisa melakukan pembayaran, maka kasusnya akan dilimpahkan ke Divisi PSO (Problem Solving Officer) yaitu divisi penanganan debitor yang terlambat melakukan kewajiban selama 3 bulan keatas. Apabila debitor dalam penanganan PSO tidak juga bisa melakukan pembayaran, maka unit dalam hal ini sepeda motor akan langsung diamankan oleh Divisi PSO.

Jika Divisi PSO tidak sanggup melakukan penarikan maka proses penarikannya akan dilakukan oleh Debt Collector (DC) yang notabene adalah karyawan eksternal perusahaan (freelance). Dalam hal sepeda motor hilang karena debitor tidak menjaganya dengan baik atau sepeda motor digadaikan tanpa sepengetahuan terlebih dahulu dari pihak Finance, maka pihak kreditor akan meminta bantuan kepada Debt Collector (DC) untuk melakukan pencarian sepeda motor yang menjadi barang jaminan tersebut.

Sebagaimana telah disebutkan bahwa sampai saat ini belum ada peraturan yang secara khusus mengatur tentang penggunaan jasa debt collector oleh lembaga pembiayaan. Namun penggunaan jasa debt collector sebagai bentuk eksternal collector dimungkinkan oleh pihak lembaga pembiayaan untuk menagih hutang terhadap pihak lain. Dalam hubungan ketenagakerjaan, salah satu perjanjian yang mungkin ada adalah perjanjian kerja. Perjanjian kerja tersebut umumnya memuat kesepakatan antara pekerja dengan perusahaan, yang dalam hal ini sering diwakili oleh manajemen atau direksi perusahaan.

Berdasarkan uraian pada pembahasan permalasana pertama bahwa pengambilan kendaraan bermotor secara paksa dalam perjanjian pembiayaan adalah konsumen telah melakukan wanprestasi (tidak membayar angsuran sesuai yang diperjanjikan), namun apabila kendaraan bermotor sebagai obyek jaminan fidusia tidak didaftarkan oleh perusahaan pembiayaan pada Kantor Fidusia, maka pengambilan paksa tersebut tidak sah, sebab hak kebendaan dari perjanjian fidusia tidak lahir, sehingga perusahaan pembiayaan selaku kreditor tidak dapat menggunakan ketentuan dalam Pasal 29 Undang-Undang Nomor 42 Tahun 1999 tentang Jaminan Fidusia. Seandainya fidusia tersebut didaftarkan sesuai Peraturan Menteri Keuangan (PMK) 
Nomor 130/PMK.010/2012 dan jika tidak didaftarkan, namun pengambilan kendaraan bermotor (eksekusinya) harus melibatkan atau mendapatkan pendampingan petugas kepolisian. Hal ini sesuai dengan Peraturan Kapolri (Perkap) Nomor 8 Tahun 2011 adalah untuk menyelenggarakan pelaksanaan eksekusi jaminan fidusia secara aman, tertib, lancar, dan dapat dipertanggungjawabkan; melindungi keselamatan penerima jaminan fidusia, pemberi jaminan fidusia, dan/atau masyarakat dari perbuatan yang dapat menimbulkan kerugian harta $^{7}$. yang menjelaskan bagaimana tata cara pengambilan objek perjanjian kredit yang di atasnya sudah melekat jaminan fidusia, dan sepengetahuan pemangku wilayah RT/RW setempat. Lebih lajut peraturan pengamanan obyek jaminan fidusia dalam Pasal 6, Peraturan Kapolri (Perkap) Nomor 8 Tahun 2011:

1. Ada permintaan dari pemohon;

2. Miliki akta jaminan fidusia;

3. Jaminan fidusia terdaftar pada kantor pendaftaran fidusia;

4. Memiliki sertifikat jaminan fidusia; dan

5. Jaminan fidusia berada di wilayah negara Indonesia."

Untuk meminta bantuan pendampingan pihak Kepolisian maka dapat diajukan permohonan ke Kepolisian setempat dari tingkat yang paling bawah yaitu Kepolisian Sektor hingga tertinggi di daerah tersebut yaitu Kepolisian Daerah (Polda), dimana permohonan bantuan pengamanan/ pendampingan eksekusi tersebut, harus diajukan secara tertulis oleh kuasa hukumnya (advokat) atau in person/ principle penerima jaminan fidusia di tempat akan eksekusi dilaksanakan. ${ }^{8}$

Kepolisian Republik Indonesia melihat dinamika masyarakat yang semakin menningkat terkait leasing dan secara khusus penggunaan jasa debt collector yang rawan menimbulkan tindak pidana, Diharapkan dengan dikeluarkannya peraturan Kapolri ini, eksekusi jaminan fidusia dilakukan dengan cara yang aman untuk melindungi hak semua pihak. Agar tidak ada lagi "nuansa" kekerasan dan/ ancaman

\footnotetext{
${ }^{7}$ Reymond I. Kalesaran, 2018, "Pengambilan Paksa Atas Barang Orang Lain Oleh Debt Collector Ditinjau Dari Pasal 362 KUHP“ Lex Crimen Vol. Vii/No. 8/Okt/ h. 28

8 Rahmat Hidayat, Soegianto, 2019, "Penyelesaian Debitor Wan Prestasi Atas Obyek Jaminan Fidusia Yang Telah Didaftarkan”, USM Law Review, Vol 2, No 2, h. 295
} 
Kelik Endro Suryono, Guruh Riona Putra: Eksekusi Sepibak Oleh Perusahaan Leasing...

kepada debitor. Disisi kreditor sendiri dengan peraturan Kapolri ini akan mendapatkan kepastian dan pengamanan hukum dalam melaksanakan eksukusi.

Lebih dalam membahas soal penggunaan debt collector, Perusahaan leasing yang menggunakan jasa debt collector sebagai penagihan kredit/angsuran dapat memiliki keterkaitan/ pertanggung jawaban sebagai pemberi kuasa, terhadap kemungkinan tindak pidana yang terjadi, meski pada umumnya untuk bad debt yang tergolong sulit tertagih atau obyek yang bernilai misalnya mobil acapkali debt collector ini merupakah "pihak ketiga" yaitu pihak yang bukan karyawan perusahaan leasing. ${ }^{9}$

\section{Pengambilan Paksa Terhadap Obyek Fidusia Dalam Kaitan Hukum Pidana}

Terhadap pengambilan paksa yang tidak sesuai dengan ketentuan yang berlaku ini, konsumen dapat mengajukan keberatan kepada perusahaan pembiayaan berdasarkan kesepakatan bersama dalam perjanjian pembiayaan, namun apabila tidak dapat diselesaikan, maka konsumen dapat melaporkan pengambilan paksa tersebut dengan dasar pasal perampasan sebagaimana yang diatur dalam Kitab Undang Undang Hukum Pidana (KUHP), lebih lanjur dalam era digital/ modern maka perilaku debt collector dapat pula dikategorikan pelanggaran terhadap UndangUndang Nomor 19 Tahun 2016 tentang Perubahan Atas Undang-Undang Nomor 11 Tahun 2008 tentang Informasi dan Transaksi Elektronik ("UU 19/2016. Penjelasan lebih lanjut tentang hal-hal terkait hukum pidana, adalah sebagai berikut:

\section{Pencurian sesuai Pasal 362 KUHP:}

Disatu sisi sepeda motor atau mungkin mobil merupakan milik kreditor (karena belum lunas), disatu sisi debitor juga sudah memiliki sebagian atau seluruhnya hak milik karena telah membayar angsuran. Berdasar rumusan norma "Barang siapa mengambil barang sesuatu, yang seluruhnya atau sebagian kepunyaan orang lain, dengan maksud untuk dimiliki secara melawan hukum, diancam karena pencurian, dengan pidana penjara paling lama lima tahun atau pidana denda paling banyak sembilan ratus rupiah".

\footnotetext{
${ }^{9}$ Maria Oktovia Isabela Deghe Ngewi, Aksi Sinurat, Pius Bere, 2019 "Pertanggungjawaban Pidana Perusahaan Pembiayaan Terhadap Eksekusi Jaminan Fidusia Oleh Debt Collector", Jurnal Proyuris Vol.1 No.1 Juli, h. 55
} 
2. Pengambilan paksa dengan disertasi kekerasan sesuai Pasal 365 ayat (1) KUHP:

Debt Collector menggunakan kekerasan dalam mengambil obyek jaminan fidusia, sehingga dapat pula dikategorikan mencuri dengan kekerasan. Rumusan norma yang digunakan adalah "Diancam penjara paling lama sembilan tahun pencurian yang didahului, disertai atau diikuti dengan kekerasan atau ancaman kekerasan, terhadap orang dengan maksud untuk mempersiapkan atau mempermudah pencurian, atau dalam hal tertangkap tangan, untuk memungkinkan melarikan diri sendiri atau peserta lainnya, atau untuk tetap menguasai barang yang dicuri”.

3. Perampasan/ pemerasan menggunakan ancaman kekerasan sesuai Pasal 368 ayat (1) KUHP:

Debt Collector dalam mengambil obyek jaminan fidusia seringkali mengandung unsur memeras untuk menyerahkan untuk memberikan barang, mengadakan atau menghapus hutang. Rumusan normanya "Barang siapa dengan maksud untuk menguntungkan diri sendiri atau orang lain secara melawan hukum, memaksa seorang dengan kekerasan atau ancaman kekerasan untuk memberikan barang sesuatu, yang seluruhnya atau sebagian adalah kepunyaan orang itu atau orang lain, atau supaya membuat hutang maupun menghapuskan piutang, diancam karena pemerasan, dengan pidana penjara paling lama sembilan tahun".

Jadi apabla terjadi pengambilan paksa kendaraan bermotor yang menjadi objek jaminan kredit di tengah jalan, konsumen harus menolak dan dapat melaporkanya ke pihak kepolisian.

4. Pengambilan obyek fidusia yang menggunakan tipu muslihat atau janjijanji palsu dapat pula dikenakan Pasal 378 KUHP.

Tidak menutup kemungkinan saat pengambilan paksa suatu obyek fidusia diawali dengan tipu muslihat atau janji-janji palsu dan/ serangkaian kebohongan sehingga dapat memenuhi unsur-unsur "Barangsiapa dengan maksud untuk menguntungkan diri sendiri atau orang lain secara melawan hukum dengan menggunakan nama palsu atau martabat (hoedaningheid) palsu; dengan tipu muslihat, ataupun rangkaian kebohongan, menggerakkan orang lain untuk 
Kelik Endro Suryono, Gurub Riona Putra: Ekesekusi Sepihak Oleb Perusabaan Leasing...

menyerahkan barang sesuatu kepadanya, atau supaya memberi utang maupun menghapuskan piutang, diancam, karena penipuan, dengan pidana penjara paling lama empat tahun".

5. Pengambilan obyek fidusia dapat pula disertai dengan ancaman kekerasan/ menakut-nakuti melalui media elektronik, sehingga dapat melanggar UU ITE

Pasal 28 ayat (1) UU ITE yang menyatakan:

Setiap Orang dengan sengaja, dan tanpa hak menyebarkan berita bohong dan menyesatkan yang mengakibatkan kerugian konsumen dalam Transaksi Elektronik.

Pasal 29 UU UU 19/2016 tentang ITE

Setiap orang dengan sengaja dan tanpa hak mengirimkan Informasi elektronik dan/atau Dokumen Elektronik yang berisi ancaman kekerasan atau menakutnakuti yang ditujukan secara pribadi.

Pasal 45B UU 19/2016 tentang ITE

Setiap Orang yang dengan sengaja dan tanpa hak mengirimkan Informasi Elektronik dan/atau Dokumen Elektronik yang berisi ancaman kekerasan atau menakut-nakuti yang ditujukan secara pribadi sebagaimana dimaksud dalam Pasal 29 dipidana dengan pidana penjara paling lama 4 (empat) tahun dan/atau denda paling banyak Rp750.000.000,00 (tujuh ratus lima puluh juta rupiah).

\section{Pengambilan Paksa Terhadap Obyek Fidusia Dalam Kaitan Hukum Perdata}

Perjanjian pembiayaan konsumen dengan jaminan fidusia dapat dikategorikan perjanjian yang bersifat timbal balik atau bilateral dan jaminan fidusia sebagai perjanjian ikutan (accesoir). Hal ini dapat dilihat dari beberapa unsur diantaranya yaitu adanya para pihak atau subjek hukum, adanya jaminan berupa kepercayaan kepada konsumen (debitor) dapat dipercaya untuk membayar angsuran sampai 
selesai, terdapat hak dan kewajiban para pihak yang harus dilaksanakan dengan baik. $^{10}$

Oleh karena itu perusahaan pembiayaan harus mendaftarkan fidusia kendaraan bermotor sebagai obyek jaminan kredit ini dimaksudkan supaya jika konsumen wanprestasi, maka perusahaan pembiayaan memiliki dasar hukum untuk melakukan penarikan kendaraan bermotor sesuai dengan prosedur yang diterdapat di dalam peraturan perundang-undangan yang berlaku. Kekuatan eksekutorial sertifikat jaminan fidusia yang sama dengan putusan pengadilan yang telah memperoleh kekuatan hukum perlu untuk dicermati. Sertifikat tersebut tidak bersifat condemnatoir, sehingga tidak dapat dipersamakan sepenuhnya dengan putusan pengadilan yang telah memperoleh kekuatan hukum tetap (non-eksekutabel), maka sering digunakan istilah hanya "setara" putusan pengadilan. Pemegang sertifikat jaminan fidusia berkedudukan seperti seseorang yang sudah memegang putusan pengadilan yang telah mempunyai kekuatan hukum tetap. ${ }^{11}$

Dalam hal konsumen wanprestasi, lembaga pembiayaan dalam menyelesaikan kreditnya sebaiknya dilakukan dengan musyawarah dengan konsumen, tanpa harus melibatkan pihak kepolisian. Sebab jika hal ini dilakukan akan menambah ongkos atau biaya, dan juga mengesankan penyelesaian yang kurang menghormati hak-hak konsumen sebagai pembeli kendaraan bermotor.

Tindakan debt collector yang menarik paksa barang, misalnya menarik sepeda motor yang menunggak kredit atau menarik barang-barang di dalam rumah karena belum dapat melunasi hutang pada leasing, merupakan perbuatan melanggar hukum. Tindakan penarikan secara paksa itu ibaratnya menutup lubang masalah dengan masalah yaitu menyelesaikan pelanggaran hukum dengan melanggar hukum yang lebih berat. Seorang debitor yang belum mampu membayar lunas hutangnya (misalnya cicilan kredit sepeda motor yang sudah jatuh tempo) adalah suatu pelanggaran hukum, yaitu melanggar perjanjian.

\footnotetext{
10 Achmad Yusuf Sutarjo, Djuwityastuti, 2018, “Akibat Hukum Debitor Wanprestasi Pada Perjanjian Pembiayaan Konsumen Dengan Obyek Jaminan Fidusia Yang Disita Pihak Ketiga” (Studi Kasus: Putusan Mahkamah Agung Nomor 3089 K/Pdt/2015) , Privat Law Vol.6, No. 1, h. 101

${ }^{11}$ Khifni Kafa Rufaida Dan Rian Sacipto, 2019, "Tinjauan Hukum Terhadap Eksekusi Objek Jaminan Fidusia Tanpa Titel Eksekutorial Yang Sah”, Refleksi Hukum, Vol. 4, No. 1, h. 38
} 
Kelik Endro Suryono, Guruh Riona Putra: Eksekusi Sepibak Oleh Perusahaan Leasing...

Dalam hal demikian kreditor (leasing) mempunyai hak untuk menarik barang yang telah diserahkan kepada debitor (pembeli sepeda motor) dengan alasan wanprestasi. Atas alasan tersebut biasanya kreditur mengutus debt collector-nya untuk menyita barang-jika tidak berhasil menagih hutang. Suatu hubungan hutang-piutang antara debitor-kredituor (penjual dan pembeli, atau penerima kredit dan bank) umumnya diawali dengan perjanjian. Seorang pembeli kendaraan/sepeda motor secara kredit adalah debitor yang melakukan perjanjian jual-beli dengan dealernya sebagai kreditor. Jika debitor wanprestasi (tidak melaksanakan kewajibannya melunasi kredit) maka berdasarkan alasan syarat batal kreditor dapat membatalkan perjanjian. Dengan batalnya perjanjian maka kreditur dapat menarik kembali barang-barang yang telah diserahkannya kepada debitor.

Namun pembatalan itu tidak serta merta dapat dilakukan oleh kreditor. Pembatalan perjanjian itu harus dinyatakan oleh putusan pengadilan. Tanpa adanya putusan pengadilan maka tidak ada pembatalan, dan tanpa pembatalan maka kreditor tidak dapat menarik barang yang telah diterima oleh debitor (melalui debt collector-nya). Jikapun kreditor tetap memaksakan diri melakukan penyitaan, maka tindakan tersebut merupakan pelanggaran hukum, karena tindakan penarikan paksa barang oleh kreditor dan debt collector-nya adalah pelanggaran hukum maka tindakan itu dapat berindikasi tindak pidana pencurian karena mengambil barang yang sebagian atau seluruhnya milik orang lain secara melawan hukum. Atas pelanggaran hukum tersebut, debitor sepeda motor berhak melaporkannya kepada polisi. Selain pencurian kreditor dan debt collector-nya juga dapat diancam tindak pidana perbuatan tidak menyenangkan kalau sudah emosional dan menggebrak-gebrak meja-dan tentunya kita sudah dapat membayangkan tindak pidana yang yang lebih kejam lagi jika sang debt collector telah berlagak menjadi arogan. Selain hal tersebut sudah diuraikan pula potensi pelanggaran terhadap pasal lain dalam KUHP maupun UU ITE.

Daripada menggunakan cara-cara kekerasan yang berpotensi melangggar hukum pidana tersebut, ada baiknya pihak leasing dalam menyelesaikan permasalahan kredit/ angasuran macet dapat menggunakan beberapa cara. Dalam hal terjadi perselisihan ada beberapa cara yang dapat dipakai untuk menyelesaikan perselisihan yang timbul dari kedua belah pihak, yaitu dengan cara sebagai 
berikut yang diharapkan dapat mencegah kekerasan oleh debt collector:

1. Perdamaian atau negosiasi, arti kata damai disini adalah bahwa antara pihak kreditor dengan pihak debitor atau konsumen mengadakan suatu perdamaia sendiri diluar Pengadilan (non litigasi).

2. Pelaksanaan perdamaian tersebut tergantung dari kedua pihak sehingga terjadilah persetujuan dari kedua belah pihak agar perselihan ini tidak dilanjutkan ke pengadilan. Perlu dijelaskan lebih lanjut bahwa perdamaian yang dilakukan kedua

3. Pengadilan, apabila upaya penyelesaian sengketa melalui upaya non litigasi gagal, para pihak dapat mengajukan gugatan ke pengadilan.

\section{PENUTUP}

\section{Kesimpulan}

Berdasarkan uraian-uraian yang telah dikemukakan sebelumnya dalam kaitannya dengan pokok permasalahan yang ada, maka dapat diambil kesimpulan sebagai berikut:

Hukum pidana umum (KUHP), maupun khusus (UU ITE) telah berupaya memberikan perlindungan dan kepastian hukum dalam eksekusi jaminan fidusia, meski dikatakan sepihak namun sebenarnya masing-masing pihak memiliki hak dan dilindungi oleh hukum, asal bertindak sesuai koridor hukum. Dan yang perlu dicermati adalah tindak debt collector di lapangan, karena berpotensi menimbulkan kekerasan atau tindak pidana, yang secara langsung maupun tidak langsung terkait dengan perusahaan atau perusahaan pemberi kuasa. Hal tersebut hingga menjadi perhatian pihak Polri dengan terbitnya Perkapolri Nomor 8 Tahun 2011, sebagai rambu-rambu dalam melindungi semua pihak.

Hukum perdata, mengenal adanya istilah wanprestasi terhadap kreditor yang dieksekusi secara sepihak oleh debt collector dalam perjanjian leasing dengan jaminan fidusia di FIF (dan penulis menganggap di perusahaan leasing lain kurang lebih sama) dalam perjanjian leasing kendaraan/sepeda motor pada setidaknya dasar hukum bagi debt collector melakukan tindakan penarikan kendaraan/ sepeda motor yang menjadi obyek kredit perjanjian leasing yaitu :

1. Dengan menggunakan dasar adanya wanprestasi sehingga perjanjian berakhir, namun syarat pengakhiran perjanjian tersebut harus melalui putusan pengadilan. 
Kelik Endro Suryono, Gurub Riona Putra: Eksekusi Sepibak Oleh Perusabaan Leasing...

2. Dengan menggunakan dasar hukum Peraturan Menteri Keuangan Nomor 130/PMK.010/2012 bahwa kreditur berhak menarik barang yang sebagai objek jaminan fidusia dengan adanya dasar sertifikat jaminan fidusia. Jadi tanpa adanya syarat tersebut, kreditor tidak dapat semena-mena menarik barang dari debtor yang wanprestasi atau terjadinya kredit macet.

3. Bentuk pertanggungjawaban debt collector atas tindakan penarikan paksa sepeda motor yang menjadi obyek kredit debitor dapat mengajukan keberatan kepada perusahaan pembiayaan berdasarkan kesepakatan bersama dalam perjanjian pembiayaan, namun apabila tidak dapat diselesaikan, maka debitor dapat melaporkan pengambilan paksa tersebut dengan dasar pasal perampasan sebagaimana yang distur dalam Kitab Undang Undang Hukum Pidana (KUHP). Jadi apabla terjadi pengambilan paksa kendaraan bermotor yang menjadi objek jaminan kredit di tengah jalan, konsumen harus menolak dan dapat melaporkanya ke pihak kepolisian.

\section{A. Saran}

Bertitik tolak kepada pembahasan permasalahan dan kesimpulan di atas, saran yang dapat saya berikan adalah :

1. Penggunaan debt collector baik internal maupun eksternal dari perusahaan leasing selayaknya dihindari, mengingat potensi penggunaan kekerasan yang mungkin terjadi. Kedepannya diharapkan penegak hukum dapat lebih detail dan bijaksana dalam melindungi para pihak baik kreditor maupun debitor demi tercapainya tujuan hukum yaitu keadilan, sehingga kesejahteraan masyarakat dapat terwujud.

2. Agar tidak terjadi perselisihan atau sengketa antara para pihak yaitu lessee dan lessor maka dalam pencantuman klausula sangat penting dibuat dan sebaiknya menggunakan akta notariil dan dilakukan pendaftaran jaminan fidusia atas benda jaminan, untuk memudahkan kreditor sendiri manakala terjadi wanprestasi oleh debitor berikut eksekusi dan penarikan terhadap objek leasing tersebut. Demikian halnya dengan kantor pendaftaran fidusia perlu dibentuk disetiap kabupaten/kota untuk memberikan kemudahan bagi kreditor pada umumnya dan lembaga pembiayaan pada khususnya untuk mendaftarkan jaminan fidusianya.

3. Apabila telah terjadi sengketa/perselisihan maka penyelesaiaannya yang dilakukan adalah lebih efektif dengan cara perdamaian atau alternatif penyelesaian sengketa 
dibandingkan dengan melalui cara penyelesaian di pengadilan sehingga bagi para pihak sebaiknya dihindari penyelesaian perselisihan di pengadilan atau bahkan dengan cara main hakim sendiri dengan melakukan penarikan paksa. Untuk menghindari risiko dalam perjanjian leasing, selain analisis pembiayaan dilaksanakan dengan baik juga dengan melibatkan adanya pihak ketiga dalam hal ini pihak asuransi untuk mencegah adanya risiko atau menjamin risiko tersebut baik dari lessee maupun lessor.

\section{DAFTAR PUSTAKA}

\section{Buku :}

Irsan, Koesparmono. 2010, Kasus-Kasus Debt Collector di Indonesia, Sinar Grafika, Semarang.

\section{Jurnal :}

Achmad Yusuf Sutarjo, Djuwityastuti, 2018, “Akibat Hukum Debitor Wanprestasi Pada Perjanjian Pembiayaan Konsumen Dengan Obyek Jaminan Fidusia Yang Disita Pihak Ketiga" (Studi Kasus: Putusan Mahkamah Agung Nomor 3089 K/Pdt/2015), Privat Law Vol.6, No. 1

Hartanto, Cut Wilda Meutia Syafiina, 2021 "Efektivitas Perlindungan Konsumen Terhadap Produk Kosmetik Yang Tidak Memiliki Izin Edar Balai Besar Pengawas Obat Dan Makanan Diy (Dalam Perspektif Hukum Pidana)", Jurnal Meta-Yuridis Vol 4, No 1

Kadek Cinthya Dwi Lestari*, I Nyoman Putu Budiartha dan Ni Made Puspasutari Ujianti, 2020, "Hilangnya Objek Jaminan Fidusia yang Tidak Didaftarkan", Jurnal Analogi Hukum, 2 (3)

Khifni Kafa Rufaida Dan Rian Sacipto, 2019, "Tinjauan Hukum Terhadap Eksekusi Objek Jaminan Fidusia Tanpa Titel Eksekutorial Yang Sah”, Refleksi Hukum, Vol. 4, No. 1

Maria Oktovia Isabela Deghe Ngewi, Aksi Sinurat, Pius Bere, 2019 "Pertanggungjawaban Pidana Perusahaan Pembiayaan Terhadap Eksekusi Jaminan Fidusia Oleh Debt Collector', Jurnal Proyuris Vol.1 No.1 Juli

Made Warka, Sudarti, 2014, "Pengambilan Paksa Kendaraan Bermotor Dan Upaya Hukum Konsumen”, Jurnal Ilmu Hukum Mimbar Keadilan, Mei - Nopember,

Peter Giovanni Handoko Suwigjo Putro, 2017, “Analisis Terhadap Dampak Dibuatnya Jaminan Fidusia Dengan Perjanjian Dibawah Tangan Oleh Bank Perkreditan Rakyat", Jurnal Hukum Uajy, Agustus

Rahmat Hidayat, Soegianto, 2019, "Penyelesaian Debitor Wan Prestasi Atas Obyek Jaminan Fidusia Yang Telah Didaftarkan", USM Law Review, Vol 2, No 2

Reymond I. Kalesaran, 2018, "Pengambilan Paksa Atas Barang Orang Lain Oleh Debt Collector Ditinjau Dari Pasal 362 KUHP“ Lex Crimen Vol. Vii/No. 8/Okt 
Kelik Endro Suryono, Gurub Riona Putra: Eksekusi Sepihak Oleb Perusahaan Leasing...

${ }^{1}$ Wawancari CMP PT. FIF Agustus 2020 